\title{
Polysubstituted Phenyl Glucosides Produced by the Fungus Metarrhizium anisopliae*
}

\author{
Wen-jing WANG, Chong DAI, Jian-ping WANG, Hu-cheng ZHU, Chun-mei CHEN", Yong-hui ZHANG ${ }^{\#}$ \\ Hubei Key Laboratory of Natural Medicinal Chemistry and Resource Evaluation, Tongji Medical College, Huazhong University \\ of Science and Technology, Wuhan 430030, China
}

(C) The Author(s) 2020, corrected publication July 2020

\begin{abstract}
Summary: Metarhizosides A-G (1-7), seven new polysubstituted phenyl glucosides, were isolated from the extracts of solid rice medium of a marine-derived fungus Metarrhizium anisopliae. Compounds 1-7 all contain a polysubstituted phenyl group and the sugar unit is identified as 4'-O-methyl- $\beta$-D-glucopyranose. Their structures were elucidated by NMR spectroscopy and chemical method. These compounds were evaluated for anti-inflammatory activity by using LPSstimulated murine macrophage RAW 264.7 cells and the cytotoxicities against four human cancer cell lines.
\end{abstract}

Key words: marine-derived fungus; glucosides; Metarrhizium anisopliae; anti-inflammation; cytotoxicities

Marine-derived fungi have recently been proved to be a significant source of secondary metabolites with structural and biological diversity ${ }^{[1,2]}$. According to the literature, more than 4000 natural compounds have been isolated from marine-derived fungi since 1945, which have attracted the attention of chemists and biologists because of their unique chemical structure and various biological activity, and are playing an increasingly important role in drug discovery and development process ${ }^{[3-11]}$. As part of our ongoing investigation on new bioactive secondary metabolites from marine-derived microorganisms, the strain Metarrhizium anisopliae (M. anisopliae), isolated from the mangrove soil, attracted our attention. M. anisopliae, an insecticidal fungus, has been reported to produce various secondary metabolites including destruxin, cytochalasin, aurovertin and cyclic hetapeptide, which exhibited extensive bioactivities ${ }^{[12-17]}$. The ethyl acetate

The original version of this article was revised due to a retrospective Open Access order.

Wen-jing WANG, E-mail: wangwj0122@163.com

\#Corresponding author, Chun-mei CHEN, E-mail: chenchunmei @hust.edu.cn; Yong-hui ZHANG, E-mail:zhangyh@mails. tjmu.edu.cn

${ }^{*}$ This work was financially supported by the Program for Changjiang Scholars of Ministry of Education of the People's Republic of China (No. T2016088), the National Natural Science Foundation for Distinguished Young Scholars (No. 81725021), the National Natural Science Foundation of China (No. 31900288), the Program from the China Postdoctoral Science Foundation (No. 2019M652660), and the Integrated Innovative Team for Major Human Diseases Program of Tongji Medical College (HUST, China).
(EtOAc) extract of the fungal culture exhibited moderate anti-inflammatory activity, furthermore, chemical investigation on this strain has resulted in the isolation of seven new polysubstituted benzene glucosides metarhizosides $A-G(\mathbf{1}-\mathbf{7})$, together with four known compounds 8-11 (fig. 1). These new structures were confirmed by extensive nuclear magnetic resonance (NMR) spectroscopy and chemical method, and they all feature a 4 '- $O$-methyl- $\beta$-glucopyranose unit. The known compounds were identified as phellinignincisterol C (8) ${ }^{[18]}$, lepistamide B $(\mathbf{9})^{[19]}$, cyclotryprostatin E $(\mathbf{1 0})^{[20]}$, 6-methoxyspirotryprostatin B (11) ${ }^{[2]}$. In the bioassay, compounds $\mathbf{1}$ and $\mathbf{2}$ showed inhibitory activity against lipopolysaccharides (LPS)-induced nitric oxide (NO) production. Herein, details of isolation, structural elucidation, and biological activities are presented.

\section{MATERIALS AND METHODS}

\subsection{General Experimental Procedures}

Thin-layer chromatography (TLC) materials were silica gel $G F_{254}\left(\mathrm{SiO}_{2}\right.$; Yantai Chemical Industry Research Institute, China). Column chromatography materials included silica gel (Qingdao Marine Chemical Inc., China), sephadex LH-20 (Pharmacia Biotech AB, Sweden) and octadecylsilyl (ODS) $(50 \mu \mathrm{m}$; YMC, Japan). NMR spectra were measured with a Bruker AM-400 NMR spectrometer (Bruker, Germany). Optical rotations were obtained on a Rudolph Autopol IV automatic polarimeter with a $0.7 \mathrm{~mL}$ cell (Rudolph Research Analytical, USA). IR spectra were taken on a Bruker Vertex 70 FT-IR spectrophotometer (Bruker, Germany). UV spectra were obtained with a PerkinElmer 

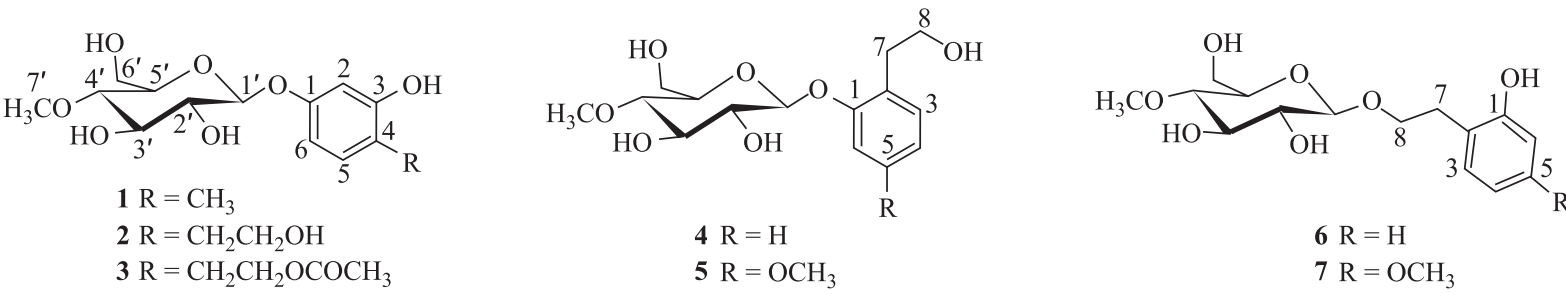

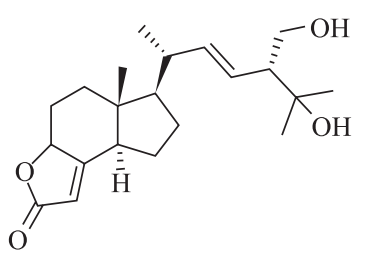

8

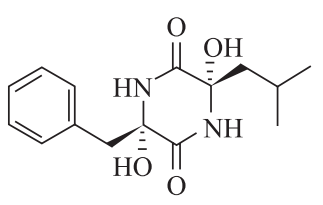

9

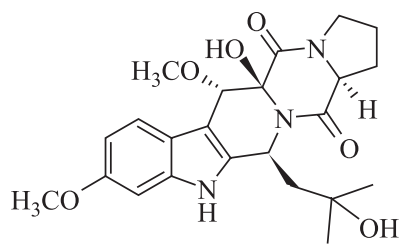

10

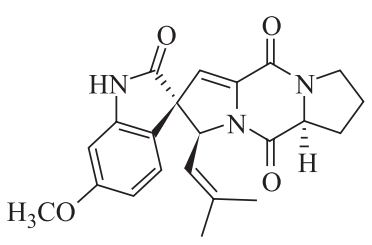

11

Fig. 1 The structures of compounds 1-11

Lambda 35 spectrophotometer (PerkinElmer, Inc., USA). ECD data were measured with a JASCO-810 instrument (JASCO Co., Ltd., Japan). HRESIMS data were acquired on Bruker micrOTOF II spectrometer. An Agilent 1260 HPLC system semi-preparative HPLC equipped with a DAD detector was used to purify the compounds. Chemical shifts are expressed in ppm with reference to the solvent peaks $\mathrm{CD}_{3} \mathrm{OD}\left(\delta_{\mathrm{H}} 3.31 / \delta_{\mathrm{C}} 49.0\right)$ and DMSO- $d_{6}\left(\delta_{\mathrm{H}} 2.50 / \delta_{\mathrm{C}} 39.52\right)$.

\subsection{Fungal Material}

The fungus $M$. anisopliae was isolated from a mangrove mud sample collected in Xiamen, China. The mud sample was suspended and diluted with sterile water, and then coated individually on potato dextrose agar (PDA) medium containing chloramphenicol. Followed by the routine microbiological methods, the single colonies were obtained ${ }^{[22]}$. The internal transcribed spacer (ITS) region of this fungus was submitted to the GenBank and identified as $M$. anisopliae with accession no. MH079423. The voucher sample MA414 was preserved in the Culture Collection Center of Tongji Medical College, Huazhong University of Science and Technology.

\subsection{Fermentation and Isolation}

The fungus MA414 was incubated on PDA at $28^{\circ} \mathrm{C}$ for 7 days. The agar was cut into small pieces and then inoculated in $100 \times 1 \mathrm{~L}$ Erlenmeyer flasks, each one contained $200 \mathrm{~g}$ rice and $200 \mathrm{~mL}$ distilled water. After incubation at $28^{\circ} \mathrm{C}$ for 21 days, the solid medium was concentrated and then distilled with $\mathrm{CH}_{3} \mathrm{CH}_{2} \mathrm{OH}$ repeatedly. After that, the EtOAc was used to extract and $80 \mathrm{~g}$ of the extraction was finally obtained. The separation of the EtOAc extract was subjected to column chromatography on silica gel (CC, 80-120 mesh) eluting with $\mathrm{CH}_{2} \mathrm{Cl}_{2}-\mathrm{MeOH}(100: 1-0: 1$, v/v) to obtain four fractions (Fr. A-Fr. D).

Fr. B (6.0 g) was separated by MPLC (MeOH$\left.\mathrm{H}_{2} \mathrm{O}, 20: 80-100: 0\right)$ to give five fractions (Fr. B1-Fr. B5). Fr. B2 was subjected to Sephadex LH-20 (MeOH) and further purified by semi-preparative $R P-C 18$ HPLC
$(\mathrm{MeOH}-\mathrm{H} 2 \mathrm{O}, 40: 60, \mathrm{v} / \mathrm{v})$ to yield 8 (5.0 mg). Fr. B3 was separated by Sephadex LH-20 (MeOH) and further purified by semi-preparative $R P-C 18 \mathrm{HPLC}(\mathrm{MeOH}-$ $\left.\mathrm{H}_{2} \mathrm{O}, 42: 58, \mathrm{v} / \mathrm{v}\right)$ to yield 9 (3.2 mg). Compounds 10 $(4.5 \mathrm{mg})$ and $11(2.2 \mathrm{mg})$ were obtained from Fr. B4 by Sephadex LH-20 $\left(\mathrm{CH}_{2} \mathrm{Cl}_{2}-\mathrm{MeOH} 1: 1\right)$ and further purified by semi-preparative HPLC $\left(\mathrm{MeCN}-\mathrm{H}_{2} \mathrm{O}\right.$, 45:55, v/v).

Fr. C (10.0 g) was fractionated and purified by MPLC (MeOH- $\left.\mathrm{H}_{2} \mathrm{O}, 20: 80-100: 0\right)$ and Sephadex LH$20\left(\mathrm{CH}_{2} \mathrm{Cl}_{2}-\mathrm{MeOH} 1: 1\right)$ to get five fractions (Fr. C1Fr. C5). Fr. C2 was further purified by semi-preparative $R P-C 18$ HPLC $\left(\mathrm{MeOH}-\mathrm{H}_{2} \mathrm{O}, 40: 60, \mathrm{v} / \mathrm{v}\right)$ to yield 1 (3.5 mg) and $2(4.2 \mathrm{mg})$. Compound 3 (2.5 mg) was obtained from Fr. C3 by semi-preparative HPLC $\left(\mathrm{MeOH}-\mathrm{H}_{2} \mathrm{O}, 43: 57, \mathrm{v} / \mathrm{v}\right)$. Fr. C4 was then separated by MPLC $\left(\mathrm{MeOH}-\mathrm{H}_{2} \mathrm{O}, 35: 65-60: 40\right)$ to get two fractions and further purified by semi-preparative $R P$ $C 18$ HPLC $\left(\mathrm{MeOH}-\mathrm{H}_{2} \mathrm{O}, 42: 58, \mathrm{v} / \mathrm{v}\right)$ to yield 4 (15.5 $\mathrm{mg}), 5(3.2 \mathrm{mg}), 6$ (2.7 mg) and 7 (3.0 mg).

Metarhizoside A (1): pale yellow oil, $[\alpha]_{D}{ }^{25}-99$ $(c=0.10, \mathrm{MeOH})$; IR $v_{\max }=3398,2926,1659,1616$, $1511,1468,1282,1172,1105,1080 \mathrm{~cm}^{-1}$; UV (MeOH) $\lambda_{\text {max }}(\log \varepsilon)=203$ (4.41), 221 (3.78), 278 (3.52) nm; for $1 \mathrm{H}$ NMR (400 MHz) and ${ }^{13} \mathrm{C}$ NMR $(100 \mathrm{MHz})$ data see tables 1 and 2; HRESIMS [M+Na] ${ }^{+} m / z 323.1119$ (calcd for $\mathrm{C}_{14} \mathrm{H}_{20} \mathrm{NaO}_{7}, 323.1107$ ).

Metarhizoside B (2): pale yellow oil, $[\alpha]_{D}{ }^{25}-63.2$ $(c=0.10, \mathrm{MeOH})$; IR $v_{\max }=3415,3388,2927,1621$, $1602,1522,1426,1282,1181,1087,1052 \mathrm{~cm}^{-1}$; UV $(\mathrm{MeOH}) \lambda_{\max }(\log \varepsilon)=202$ (3.95), 212 (3.74), 270 (3.32) nm; for ${ }^{1} \mathrm{H}$ NMR (400 MHz) and ${ }^{13} \mathrm{C} \mathrm{NMR} \mathrm{(100}$ $\mathrm{MHz}$ ) data see tables 1 and 2; HRESIMS [M+Na] ${ }^{+} \mathrm{m} / \mathrm{z}$ 353.1218 (calcd for $\mathrm{C}_{15} \mathrm{H}_{22} \mathrm{NaO}_{8}, 353.1212$ ).

Metarhizoside $\mathbf{C}$ (3): pale yellow oil, $[\alpha]_{\mathrm{D}}^{25}$ $44.5(c=0.10, \mathrm{MeOH})$; IR $v_{\max }=3398,2834,1718$, $1619,1519,1435,1387,1280,1106,1081,1054 \mathrm{~cm}^{-1}$; UV $(\mathrm{MeOH}) \lambda_{\max }(\log \varepsilon)=203$ (4.45), 220 (3.72), 278 (3.55) nm; for ${ }^{1} \mathrm{H}$ NMR (400 MHz) and ${ }^{13} \mathrm{C} \mathrm{NMR} \mathrm{(100}$ $\mathrm{MHz})$ data see tables 1 and 2; HRESIMS $[\mathrm{M}+\mathrm{Na}]^{+} \mathrm{m} / \mathrm{z}$ 
359.1338 (calcd for $\mathrm{C}_{17} \mathrm{H}_{24} \mathrm{NaO}_{9}, 359.1318$ ).

Metarhizoside D (4): pale yellow oil, $[\alpha]_{D}^{25}-49.5$ $(c=0.10, \mathrm{MeOH}) ; \mathrm{IR} v_{\max }=3360,2930,2889,1606$, 1497, 1456, 1395, 1237, 1116, 1097, $1054 \mathrm{~cm}^{-1}$; UV $(\mathrm{MeOH}) \lambda_{\max }(\log \varepsilon)=202$ (4.03), 212 (3.83), 278 (3.45) nm; for ${ }^{1} \mathrm{H}$ NMR (400 MHz) and ${ }^{13} \mathrm{C}$ NMR (100 $\mathrm{MHz}$ ) data see tables 1 and 2; HRESIMS $[\mathrm{M}+\mathrm{Na}]^{+} \mathrm{m} / \mathrm{z}$ 337.1272 (calcd for $\mathrm{C}_{15} \mathrm{H}_{25} \mathrm{NaO}_{7}, 337.1263$ ).

Metarhizoside E (5): pale yellow oil, $[\alpha]_{\mathrm{D}}^{25}-57.0$ $(c=0.10, \mathrm{MeOH}) ; \mathrm{IR} v_{\text {max }}=3328,2931,1616,1512$, $1283,1203,1111,1048 \mathrm{~cm}^{-1}$; UV (MeOH) $\lambda_{\text {max }}(\log \varepsilon)$ $=202$ (4.43), 223 (3.87), 278 (3.45) nm; for ${ }^{1} \mathrm{H}$ NMR (400 MHz) and ${ }^{13} \mathrm{C}$ NMR (100 MHz) data see tables 1 and 2; HRESIMS [M+Na] ${ }^{+} \mathrm{m} / \mathrm{z} 367.1380$ (calcd for $\left.\mathrm{C}_{16} \mathrm{H}_{24} \mathrm{NaO}_{8}, 367.1369\right)$.

Metarhizoside F (6): pale yellow oil, $[\alpha]_{\mathrm{D}}{ }^{25}-28.7$ $(c=0.10, \mathrm{MeOH}) ; \mathrm{IR} v_{\max }=3394,2931,1595,1457$, $1377,1241,1109,1083,1029 \mathrm{~cm}^{-1}$; UV (MeOH) $\lambda_{\text {max }}$ $(\log \varepsilon)=203$ (4.13), $214(3.67), 274(3.25) \mathrm{nm}$; for ${ }^{1} \mathrm{H}$ NMR $(400 \mathrm{MHz})$ and ${ }^{13} \mathrm{C}$ NMR $(100 \mathrm{MHz})$ data see Tables 1 and 2; HRESIMS [M+Na] ${ }^{+} m / z 337.1268$ (calcd for $\mathrm{C}_{15} \mathrm{H}_{22} \mathrm{NaO}_{7}, 337.1263$ ).

Metarhizoside G (7): pale yellow oil, $[\alpha]_{\mathrm{D}}{ }^{25}-41.0$ $(c=0.10, \mathrm{MeOH})$; IR $v_{\max }=3393,2938,1620,1521$, $1433,1289,1201,1163,1109,1029 \mathrm{~cm}^{-1}$; UV (MeOH) $\lambda_{\text {max }}(\log \varepsilon)=203$ (4.42), 221 (3.67), 278 (3.35) nm; for ${ }^{1} \mathrm{H}$ NMR $(400 \mathrm{MHz})$ and ${ }^{13} \mathrm{C}$ NMR $(100 \mathrm{MHz})$ data see Tables 1 and 2; HRESIMS [M+Na] $m / z 367.1373$ (calcd for $\mathrm{C}_{16} \mathrm{H}_{24} \mathrm{NaO}_{8}, 367.1369$ ).

\subsection{Hydrolysis of 4}

Compound $4(10 \mathrm{mg})$ was hydrolyzed in $3 \mathrm{~mL} \mathrm{5 \%}$ aqueous hydrochloric acid and heated up to $90^{\circ} \mathrm{C}$ for $14 \mathrm{~h}$. The reaction fluid was extracted by $3 \mathrm{~mL}$ EtOAc three times, and then the solvent of the aqueous layer was evaporated under reduced pressure to get a mixed production. The mixture was further purified by semipreparative HPLC to obtain an anomeric mixture of 4'-O-methyl-glucopyranose $(2.3 \mathrm{mg})$ and the optical rotation was $[\alpha]_{\mathrm{D}}{ }^{25}+53.7(c \quad 0.1, \mathrm{MeOH})$. The EtOAc layer $(7.0 \mathrm{mg})$ was concentrated in vacuo and then identified as 2-(2-hydroxyethyl) phenol.

\subsection{Biological Assays}

1.5.1 Anti-inflammatory Activity Anti-inflammatory activity of the new compounds was evaluated using the ELISA with indomethacin and dexamethasone serving as the positive controls ${ }^{[23]}$. RAW 264.7 cells were cultured in DMEM (HyClone, Logan, USA) supplemented with $10 \%$ heat inactivated fetal bovine serum (FBS) (HyClone) at $37^{\circ} \mathrm{C}$ in a humidified atmosphere with $5 \% \quad \mathrm{CO}_{2}$. Then the cells were inoculated in 48 -well microtiter plates at $1 \times 10^{4}$ cells/ well for $24 \mathrm{~h}$, then the test compounds $(40 \mu \mathrm{mol} / \mathrm{L})$ were added to the wells. Three hours later, the LPS with a concentration of $100 \mathrm{ng} / \mathrm{mL}$ was added, and the incubation was continued for $24 \mathrm{~h}$ at $37^{\circ} \mathrm{C}$. The NO level in the supernatant was determined according to the manufacturer's instructions (Boster Biological Technology Co., Ltd., China) using ELISA.

1.5.2 Cytotoxicity against Cancer Cell Lines Cytotoxicity of the selected compounds against four cancer cell lines (HepG2, HL-60, A549 and MCF-7), was evaluated using the MTT method with doxorubicin as positive controls ${ }^{[24]}$. All the cells were cultured in RPMI.1640 medium (Hangzhou Jinuo Biology Technology Co., Ltd., China), supplemented with 10\% FBS (ExCell Biology Co., Ltd., China), $100 \mu \mathrm{g} / \mathrm{mL}$ streptomycin (Solarbio) and 100 units $/ \mathrm{mL}$ penicillin at $37^{\circ} \mathrm{C}$ in a humidified atmosphere with $5 \% \mathrm{CO}_{2}$. Then the tumor cells were inoculated in 96-well plates at a density of 5000 cells/well to incubate for $24 \mathrm{~h}$. After that, test compounds $(40 \mu \mathrm{mol} / \mathrm{L})$ were added to the wells and incubated for another $48 \mathrm{~h}, 20 \mu \mathrm{L} 5 \mathrm{mg} / \mathrm{mL}$ 3-(4,5-dimethylthiazol-2-yl)-2,5-diphenyltetrazolium bromide (MTT, Solarbio) was added, and the incubation was continued for $4 \mathrm{~h}$ at $37^{\circ} \mathrm{C}$. The MTT assay results were obtained using a microplate spectrophotometer (SpectraMax ${ }^{\circledR}$ I3, Molecular Devices, USA).

\section{RESULTS}

Metarhizoside A(1) was isolated as pale yellow oil. The molecular formula of $\mathrm{C}_{14} \mathrm{H}_{20} \mathrm{O}_{7}$, with five degrees of unsaturation, was deduced by high resolution electrospray ionization mass spectrometry (HRESIMS) from the pseudomolelar ion peak at $\mathrm{m} / \mathrm{z} 323.1119$ [M+ $\mathrm{Na}]^{+}$. The infrared (IR) spectrum of 1 showed a strong $\mathrm{O}-\mathrm{H}$ stretching band at $3398 \mathrm{~cm}^{-1}$. The ${ }^{1} \mathrm{H}$ NMR data (table 1) of 1 showed the presence of three olefinic protons resonating at $\delta_{\mathrm{H}} 6.90(1 \mathrm{H}, \mathrm{d}, J=8.1 \mathrm{~Hz}), 6.59$ $(1 \mathrm{H}, \mathrm{d}, J=2.4 \mathrm{~Hz})$, and $6.36(1 \mathrm{H}, \mathrm{dd}, J=8.1,2.4 \mathrm{~Hz})$, which were presumed to be an $\mathrm{ABX}$ spin system on the phenyl group. Other signals remained including a methyl singlet at $\delta_{\mathrm{H}} 2.15(3 \mathrm{H}, \mathrm{s})$, a methoxy group at $\delta_{\mathrm{H}} 3.59(3 \mathrm{H}, \mathrm{s})$, and seven oxygenated protons $\left[\delta_{\mathrm{H}} 4.81\right.$ $(1 \mathrm{H}, \mathrm{d}, J=7.6 \mathrm{~Hz}), 3.86(1 \mathrm{H}, \mathrm{dd}, J=12.1,2.2 \mathrm{~Hz})$, $3.72(1 \mathrm{H}, \mathrm{dd}, J=12.1,4.5 \mathrm{~Hz}), 3.55(1 \mathrm{H}, \mathrm{t}, J=6.9$ $\mathrm{Hz}), 3.48(1 \mathrm{H}, \mathrm{dd}, J=9.3,7.6 \mathrm{~Hz}), 3.38(1 \mathrm{H}, \mathrm{dd}, J=$ 9.8, $4.5 \mathrm{~Hz})$ and $3.21(1 \mathrm{H}, \mathrm{dd}, J=9.8,8.9 \mathrm{~Hz})]$. The ${ }^{13} \mathrm{C}$ NMR and DEPT data (table 2) showed 14 carbon resonances, comprising six olefinic carbons $\left[\delta_{\mathrm{C}} 157.6\right.$ (C-1), 103.9 (C-2), 157.3 (C-3), 119.4 (C-4), 131.8 $(\mathrm{C}-5)$ and $109.8(\mathrm{C}-6)]$, seven oxygenated carbons $\left[\delta_{\mathrm{C}}\right.$ 102.3 (C-1'), 75.0 (C-2'), 78.2 (C-3'), 80.5 (C-4'), 77.1 $\left(\mathrm{C}-5^{\prime}\right), 62.0\left(\mathrm{C}-6^{\prime}\right)$ and $\left.60.9\left(\mathrm{C}-7^{\prime}\right)\right]$, a methyl group $\left[\delta_{\mathrm{C}}\right.$ $15.6(\mathrm{C}-7)]$. These data indicated that compound $\mathbf{1}$ was a phenyl glycoside derivative.

More structural details were derived from twodimensional (2D) NMR spectral analyses (fig. 2). The correlation spectroscopy (COSY) cross signals between $\mathrm{H}-1^{\prime} / \mathrm{H}-2^{\prime} / \mathrm{H}-3^{\prime} / \mathrm{H}-4^{\prime} / \mathrm{H}-5^{\prime} / \mathrm{H}-6^{\prime}$, vicinal coupling constants $\left(J_{1^{\prime}, 2^{\prime}}=7.6 \mathrm{~Hz}, J_{2^{\prime}, 3^{\prime}}=9.3 \mathrm{~Hz}, J_{3^{\prime}, 4^{\prime}}=\right.$ $8.9 \mathrm{~Hz}, J_{4^{\prime}, 5^{\prime}}=9.8 \mathrm{~Hz}$ ) and key correlations between $\mathrm{H}-$ 
$1^{\prime} / \mathrm{H}-3^{\prime}$ and $\mathrm{H}-1^{\prime} / \mathrm{H}-5^{\prime}$ in the nuclear overhauser effect spectroscopy (NOESY) spectrum demonstrated the sugar portion of compound $\mathbf{1}$ was glucopyranose ${ }^{[25]}$. At the meantime, the 4'-OH was methylated on the glucose unit that was identified by heteronuclear multiple bond correlation (HMBC) signals from $\mathrm{H}-7^{\prime}$ to $\mathrm{C}-4^{\prime}$, and $\mathrm{H}-4^{\prime}$ to $\mathrm{C}-7^{\prime}$. Based on the chemical shift $\left(\delta_{\mathrm{H}} 4.81\right)$ and coupling constant $(J=7.6 \mathrm{~Hz})$ of the anomeric proton, the glycosyl unit was identified as $4^{\prime}-O$-methyl- $\beta$ glucopyranose ${ }^{[26]}$. The observed correlations from $\mathrm{H}_{3}-7$ to C-3, C-4 and C-5, from H-3 to C-2 and C-6 and from $\mathrm{H}-5$ to $\mathrm{C}-1$ and $\mathrm{C}-3$ in HMBC spectrum suggested the presence of the 1,3,4-trisubstituted benzene ring. Further HMBC correlation from the anomeric proton $\left(\mathrm{H}-1^{\prime}\right)$ to $\mathrm{C}-1$ revealed the location of the glycosyl at $\mathrm{C}-1$ of the benzene ring. Combined with the molecular formula, the structure of $\mathbf{1}$ was ultimately concluded as shown in fig. 2.

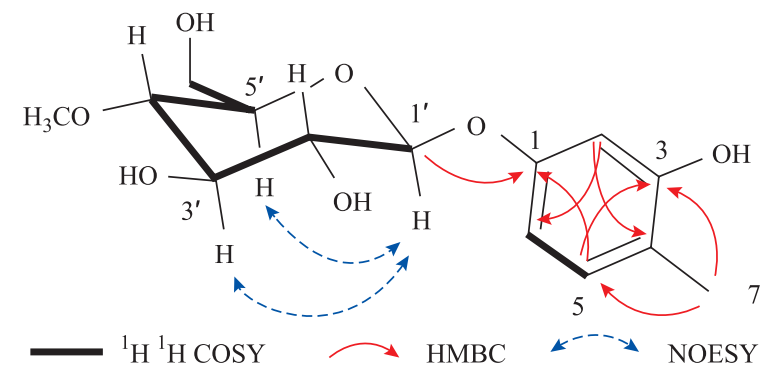

Fig. 2 Key ${ }^{1} \mathrm{H}^{-1} \mathrm{H}$ COSY, HMBC, and NOESY correlations of compound 1

Metarhizoside B (2) was also isolated as pale yellow oil. Its molecular formula was determined to be $\mathrm{C}_{15} \mathrm{H}_{22} \mathrm{O}_{8}$ based on its HRESIMS data. Subsequent comparison of the ${ }^{1} \mathrm{H}$ and ${ }^{13} \mathrm{C}$ NMR data of 2 (tables $\mathbf{1}$ and 2) with those of $\mathbf{1}$ confirmed that $\mathbf{2}$ was also a glycoside derivative. Further analysis of their 2D NMR spectroscopic data revealed the same glycosyl moiety as $4^{\prime}-O$-methyl- $\beta$-glucopyranose, while the methyl at C-6 of the aglycone was replaced by hydroxyethyl in 2 . Furthermore, key HMBC correlation from H-1' to C-1 demonstrated the same location of the glycosyl moiety. Therefore, the structure of $\mathbf{2}$ was established as shown.

Compound $\mathbf{3}$ was called metarhizoside $\mathrm{C}$ and obtained as pale yellow oil. The molecular formula of $\mathrm{C}_{17} \mathrm{H}_{24} \mathrm{O}_{9}$ with 6 degrees of unsaturation was deduced from the HRESIMS spectrum. The similar NMR data of 3 and 2 (tables 1 and 2) revealed the resembled structure of them. Detailed analysis of their 2D NMR spectroscopic data showed that compound $\mathbf{3}$ was an acetylization derivative of $\mathbf{2}$, which was further confirmed by the molecular formula. Thus, compound 3 was deduced as shown.

Metarhizoside D (4) possessed the molecular formula of $\mathrm{C}_{15} \mathrm{H}_{22} \mathrm{O}_{7}$ based on its HRESIMS spectrum. Analysis of the 1D NMR spectra revealed that compound 4 features the same sugar unit of 4'- $O$-methyl$\beta$-glucopyranose as those of $\mathbf{1}, \mathbf{2}$, and $\mathbf{3}$. The rest ${ }^{1} \mathrm{H}$
NMR data (table 1) of $\mathbf{4}$ showed signals corresponding to four olefinic protons at $\delta_{\mathrm{H}} 7.15(1 \mathrm{H}, \mathrm{d}, J=7.1 \mathrm{~Hz})$, $7.13(1 \mathrm{H}, \mathrm{t}, J=7.3 \mathrm{~Hz}), 7.05(1 \mathrm{H}, \mathrm{d}, J=7.1 \mathrm{~Hz}), 9.91$ $(1 \mathrm{H}, \mathrm{td}, J=7.3,1.2 \mathrm{~Hz})$, which suggested the presence of an ortho substituted benzene ring. Observed HMBC correlation from $\mathrm{H}-1^{\prime}$ to $\mathrm{C}-1$ revealed that the sugar moiety was connected to the aglycone unit at $\mathrm{C}-1$ of the benzene ring. Another substitution on the benzene ring was identified as hydroxyethyl and further confirmed by HMBC correlations from $\mathrm{H}-7$ to $\mathrm{C}-1$ and $\mathrm{C}-3$ and COSY correlation between $\mathrm{H}-7 / \mathrm{H}-8$. As a result, the structure of $\mathbf{4}$ was established as shown.

The molecular formula of metarhizoside E (5) was identified as $\mathrm{C}_{16} \mathrm{H}_{24} \mathrm{O}_{8}$ from the HRESIMS data; this formula contains 30 mass units $\left(\mathrm{OCH}_{2}\right)$ more than that of 4 . The ${ }^{1} \mathrm{H}$ NMR data (table 1 ) of $\mathbf{5}$ showed three olefinic protons at $\delta \mathrm{H} 7.03(1 \mathrm{H}, \mathrm{d}, J=8.3 \mathrm{~Hz}), 6.67(1 \mathrm{H}$, d, $J=2.5 \mathrm{~Hz}), 6.49(1 \mathrm{H}, \mathrm{dd}, J=8.3,2.5 \mathrm{~Hz})$, which were presumed to be an ABX spin-coupled system on the benzene ring. Subsequent comparison of the 1D NMR data of 5 (tables 1 and 2) with those of $\mathbf{4}$ confirmed that they shared the same skeleton, except for an additional methoxy group substitution on the benzene ring of $\mathbf{5}$. Furthermore, the location of the methoxy group at C-5 was identified by key $\mathrm{HMBC}$ correlation from $5-\mathrm{OCH}_{3}$ to C-5. Accordingly, the structure of $\mathbf{5}$ was deduced as shown.

Metarhizoside F (6) was also isolated as pale yellow oil. The positive-mode HRESIMS spectrum of 6 exhibited a $[\mathrm{M}+\mathrm{Na}]^{+}$ion peak at $\mathrm{m} / \mathrm{z} 337.1268$ that is consistent with a molecular formula of $\mathrm{C}_{15} \mathrm{H}_{22} \mathrm{O}_{7}$, which was the same as that of 4 . Similar to that observed for 4, the 1D NMR data (tables 1 and 2) recorded for 6 revealed the existence of the same sugar unit as $4^{\prime}-O$-methyl- $\beta$-glucopyranose and the substituted benzene ring. However, the chemical shift of the sugar anomeric proton in $\mathbf{6}$ was reduced by $0.6 \mathrm{ppm}$ while the chemical shift of C-8 and C-1' was increased by 7.4 and $2.0 \mathrm{ppm}$ respectively, suggesting that the connection between the sugar moiety and aglycone unit has changed. Observed HMBC correlations from $\mathrm{H}-1^{\prime}\left(\delta_{\mathrm{H}} 4.15\right)$ to $\mathrm{C}-8\left(\delta_{\mathrm{C}} 68.4\right)$ and $\mathrm{H}-8\left(\delta_{\mathrm{H}} 3.87,3.56\right)$ to $\mathrm{C}-1^{\prime}\left(\delta_{\mathrm{C}} 102.8\right)$ (fig. 3$)$ revealed the sugar unit was incorporated into the benzene ring through the $-\mathrm{CH}_{2} \mathrm{CH}_{2} \mathrm{O}$ - substitution at $\mathrm{C}-2$. Therefore, compound 6 was deduced as shown.

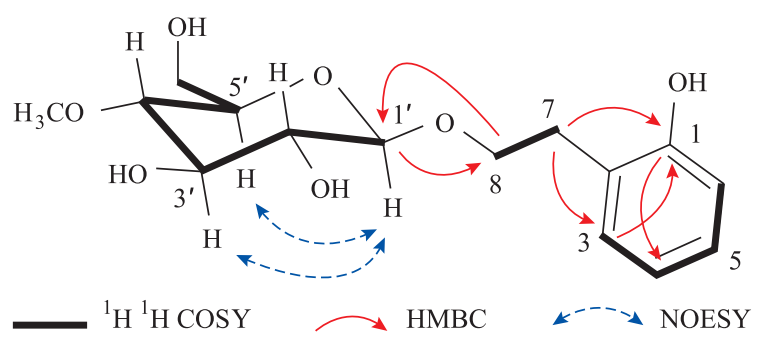

Fig. 3 Key ${ }^{1} \mathrm{H}^{-1} \mathrm{H}$ COSY, HMBC, and NOESY correlations of compound 6 
Metarhizoside G (7) gave a $[\mathrm{M}+\mathrm{Na}]^{+}$ion peak in the HRESIMS spectrum at $\mathrm{m} / \mathrm{z} 367.1373$ (calcd. for $\mathrm{C}_{16} \mathrm{H}_{24} \mathrm{NaO}_{8}, 367.1369$ ) appropriate for a molecular formula of $\mathrm{C}_{16} \mathrm{H}_{24} \mathrm{O}_{8}$, which contains 30 mass units $\left(\mathrm{OCH}_{2}\right)$ more than that of $\mathbf{6}$. The $1 \mathrm{H}$ NMR data (table 1) of 7 showed the sugar anomeric proton at $\delta_{\mathrm{H}} 4.15$, suggesting the same connection of the sugar moiety and aglycone unit. At the meantime, the 1H NMR spectrum gave three olefinic protons at $\delta \mathrm{H} 6.99(1 \mathrm{H}, \mathrm{d}, J=8.3$ $\mathrm{Hz}), 6.37(1 \mathrm{H}, \mathrm{d}, J=2.6 \mathrm{~Hz})$ and $6.29(1 \mathrm{H}, \mathrm{dd}, J=8.3$, $2.6 \mathrm{~Hz}$ ), which led to another methoxyl substitution on the benzene ring at $\mathrm{C}-5$ and was further confirmed by the key HMBC correlation from $5-\mathrm{OCH}_{3}\left(\delta_{\mathrm{H}} 3.65\right)$ to C-5 $\left(\delta_{\mathrm{C}} 158.8\right)$. Thus, the structure of 7 was ultimately concluded as shown.

Table $1{ }^{1} \mathrm{H}$ NMR Data for Compounds 1-7 (400 MHz, $J$ in $\left.\mathrm{Hz}\right)$

\begin{tabular}{|c|c|c|c|c|c|c|c|}
\hline Position & $1^{a}$ & $2^{b}$ & $3^{b}$ & $4^{b}$ & $5^{b}$ & $6^{b}$ & $7^{b}$ \\
\hline 2 & $6.59 \mathrm{~d}(2.4)$ & $6.46 \mathrm{~d}(2.4)$ & $6.49 \mathrm{~d}(2.5)$ & & & & \\
\hline 3 & & & & $7.15 \mathrm{~d}(7.1)$ & $7.03 \mathrm{~d}(8.3)$ & $6.78 \mathrm{~d}(8.0)$ & $6.37 \mathrm{~d}(2.6)$ \\
\hline 4 & & & & $\begin{array}{l}6.91 \mathrm{td} \\
(7.3,1.2)\end{array}$ & $\begin{array}{c}6.49 \mathrm{dd} \\
(8.3,2.5)\end{array}$ & $\begin{array}{c}7.00 \mathrm{td} \\
(7.7,1.4)\end{array}$ & \\
\hline 5 & $6.90 \mathrm{~d}(8.1)$ & $6.93 \mathrm{~d}(8.3)$ & $6.95 \mathrm{~d}(8.4)$ & $7.13 \mathrm{~d}(7.3)$ & & $6.70 \mathrm{t}(7.4)$ & $\begin{array}{l}6.29 \mathrm{dd} \\
(8.3,2.6)\end{array}$ \\
\hline 6 & $\begin{array}{l}6.36 \mathrm{dd} \\
(8.1,2.4)\end{array}$ & $\begin{array}{l}6.39 \mathrm{dd} \\
(8.3,2.4)\end{array}$ & $\begin{array}{c}6.41 \mathrm{dd} \\
(8.4,2.5)\end{array}$ & $7.05 \mathrm{~d}(7.1)$ & $6.67 \mathrm{~d}(2.5)$ & $\begin{array}{c}7.10 \mathrm{dd} \\
(7.4,1.7)\end{array}$ & $6.99 \mathrm{~d}(8.3)$ \\
\hline 7 & $2.15 \mathrm{t}(7.3)$ & $2.61 \mathrm{t}(7.3)$ & $2.75 \mathrm{t}(7.1)$ & $2.79 \mathrm{~m}$ & $2.70 \mathrm{~m}$ & $2.80 \mathrm{~m}$ & $2.72 \mathrm{~m}$ \\
\hline $8 \mathrm{a}$ & & $3.50 \mathrm{~m}$ & $4.10 \mathrm{t}(7.1)$ & $3.58 \mathrm{t}(7.2)$ & $3.52 \mathrm{t}(7.7)$ & $\begin{array}{c}3.87 \mathrm{td} \\
(9.4,6.3)\end{array}$ & $\begin{array}{l}3.82 \mathrm{td} \\
(9.3,6.3)\end{array}$ \\
\hline $8 b$ & & & & & & & $\begin{array}{c}3.53 \mathrm{dd} \\
(9.3,6.0)\end{array}$ \\
\hline $5-\mathrm{OCH}_{3}$ & & & & & $3.69 \mathrm{~s}$ & & $3.65 \mathrm{~s}$ \\
\hline Acetyl & & & $1.97 \mathrm{~s}$ & & & & \\
\hline $1^{\prime}$ & $4.81 \mathrm{~d}(7.6)$ & $4.72 \mathrm{~d}(7.8)$ & $4.74 \mathrm{~d}(7.8)$ & $4.80 \mathrm{~d}(7.8)$ & $4.78 \mathrm{~d}(7.8)$ & $4.17 \mathrm{~d}(7.9)$ & $4.15 \mathrm{~d}(7.8)$ \\
\hline $2^{\prime}$ & $\begin{array}{l}3.48 \mathrm{dd} \\
(9.3,7.6)\end{array}$ & $3.19 \mathrm{~m}$ & $\begin{array}{l}3.19 \mathrm{td} \\
(8.5,5.1)\end{array}$ & $3.28 \mathrm{t}(8.2)$ & $3.27 \mathrm{t}(9.7)$ & $2.97 \mathrm{t}(8.4)$ & $2.97 \mathrm{t}(8.4)$ \\
\hline $3^{\prime}$ & $3.55 \mathrm{t}(6.9)$ & $\begin{array}{c}3.38 \mathrm{td} \\
(9.0,5.4)\end{array}$ & $3.38 \mathrm{~m}$ & $3.41 \mathrm{t}(9.3)$ & $3.41 \mathrm{~m}$ & $3.28 \mathrm{t}(9.0)$ & $3.28 \mathrm{t}(9.0)$ \\
\hline $4^{\prime}$ & $\begin{array}{c}3.21 \mathrm{dd} \\
(9.8,8.9)\end{array}$ & $3.04 \mathrm{t}(9.3)$ & $3.05 \mathrm{t}(9.3)$ & $3.05 \mathrm{t}(9.3)$ & $3.01 \mathrm{t}(9.7)$ & $2.93 \mathrm{t}(8.6)$ & $2.93 \mathrm{t}(9.3)$ \\
\hline $5^{\prime}$ & $\begin{array}{c}3.38 \mathrm{ddd} \\
(9.8,4.5,2.2)\end{array}$ & $\begin{array}{c}3.27 \mathrm{ddd} \\
(9.8,4.4,2.0)\end{array}$ & $3.28 \mathrm{~m}$ & $3.34 \mathrm{~m}$ & $3.38 \mathrm{~m}$ & $\begin{array}{c}3.10 \mathrm{ddd} \\
(9.8,4.9,2.0)\end{array}$ & $\begin{array}{c}3.10 \mathrm{ddd} \\
(9.8,4.9,2.0)\end{array}$ \\
\hline $6^{\prime} \mathrm{a}$ & $\begin{array}{c}3.86 \mathrm{dd} \\
(12.1,2.2)\end{array}$ & $\begin{array}{c}3.63 \mathrm{ddd} \\
(11.9,4.9,2.0)\end{array}$ & $3.63 \mathrm{~m}$ & $\begin{array}{c}3.64 \mathrm{brd} \\
(11.6)\end{array}$ & $\begin{array}{c}3.65 \mathrm{brd} \\
(11.5)\end{array}$ & $3.60 \mathrm{~m}$ & $3.61 \mathrm{~d}(11.5)$ \\
\hline $6^{\prime} \mathrm{b}$ & $\begin{array}{c}3.72 \mathrm{dd} \\
(12.1,4.5)\end{array}$ & $3.49 \mathrm{~m}$ & $3.51 \mathrm{~m}$ & $3.51 \mathrm{~m}$ & $3.49 \mathrm{~m}$ & $\begin{array}{c}3.47 \mathrm{dd} \\
(12.0,4.7)\end{array}$ & $3.48 \mathrm{~m}$ \\
\hline 4'- $-\mathrm{OCH}_{3}$ & $3.59 \mathrm{~s}$ & $3.45 \mathrm{~s}$ & $3.45 \mathrm{~s}$ & $3.46 \mathrm{~s}$ & $3.46 \mathrm{~s}$ & $3.42 \mathrm{~s}$ & $3.42 \mathrm{~s}$ \\
\hline
\end{tabular}

To determine the absolute configuration of the sugar unit in these new structures, compound $\mathbf{4}$ was selected to be acid hydrolysis ${ }^{[27]}$. The sugar fragment obtained from the hydrolysate aqueous layer gave positive specific rotation sign of $[\alpha]_{D}^{25}+53.7$ (c 0.1 , $\mathrm{MeOH}$ ), which indicated the D-configuration of the 4-O-methylglucopyranose as the consistency of experimental data and literature data $[\alpha]_{\mathrm{D}}^{26}+80(c$ 1.3, $\mathrm{MeOH})^{[26,28]}$.

In the bioassay, new compounds (1-7) were investigated for their anti-inflammatory activity by using LPS-stimulated murine macrophage RAW 264.7 cells and the cytotoxicity against four human cancer cell lines (HepG2, HL-60, A549, and MCF-7). As a result, compounds $\mathbf{1}$ and $\mathbf{2}$ showed moderate inhibitory activity against NO production at a concentration of $40 \mu \mathrm{mol} / \mathrm{L}$ with indomethacin and dexamethasone as the positive control (fig. 4). However, none of these glycoside compounds showed cytotoxicity against selected cancer cell lines including HepG2, HL-60, A549, and MCF-7 at $40 \mu \mathrm{mol} / \mathrm{L}$.

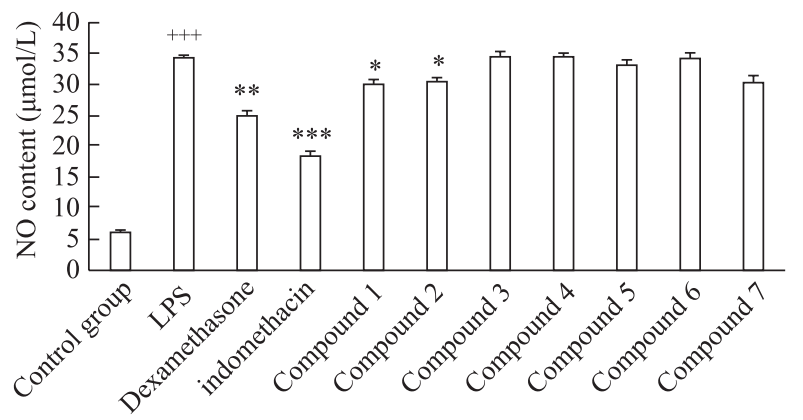

Fig. 4 NO level in LPS-stimulated RAW264.7 cells with concentration of compounds at $40 \mu \mathrm{mol} / \mathrm{L}\left({ }^{*} P<0.05\right.$, ${ }^{* *} P<0.01,{ }^{* * *} P<0.001$ vs. LPS group; ${ }^{++} P<0.001$ vs. control group) 
Table $2{ }^{13} \mathrm{C}$ NMR data for compounds 1-7 (100 MHz)

\begin{tabular}{|c|c|c|c|c|c|c|c|}
\hline Position & $1^{a}$ & $2^{b}$ & $3^{b}$ & $4^{b}$ & $5^{b}$ & $6^{b}$ & $7^{b}$ \\
\hline 1 & 157.6 & 156.6 & 157.0 & 155.6 & 156.3 & 124.4 & 116.5 \\
\hline 2 & 103.9 & 103.7 & 103.6 & 128.3 & 120.2 & 155.3 & 156.2 \\
\hline 3 & 157.3 & 155.9 & 156.0 & 130.4 & 130.6 & 114.9 & 101.2 \\
\hline 4 & 119.4 & 119.0 & 117.3 & 121.6 & 106.6 & 127.3 & 158.8 \\
\hline 5 & 131.8 & 130.7 & 130.8 & 127.2 & 158.6 & 118.9 & 104.2 \\
\hline 6 & 109.8 & 106.5 & 106.6 & 114.6 & 101.6 & 130.6 & 131.0 \\
\hline 7 & 15.6 & 33.2 & 28.7 & 33.4 & 32.8 & 30.4 & 29.8 \\
\hline 8 & & 61.1 & 63.3 & 61.0 & 61.3 & 68.4 & 68.7 \\
\hline $5-\mathrm{OCH}_{3}$ & & & & & 55.0 & & 54.9 \\
\hline Acetyl & & & 170.3 & & & & \\
\hline & & & 20.8 & & & & \\
\hline $1^{\prime}$ & 102.3 & 100.4 & 100.3 & 100.8 & 100.8 & 102.8 & 102.8 \\
\hline $2^{\prime}$ & 75.0 & 73.4 & 73.4 & 73.7 & 73.6 & 73.7 & 73.7 \\
\hline $3^{\prime}$ & 78.2 & 76.3 & 76.3 & 76.4 & 76.4 & 76.6 & 76.6 \\
\hline $4^{\prime}$ & 80.5 & 78.9 & 78.9 & 79.1 & 79.3 & 79.3 & 79.4 \\
\hline $5^{\prime}$ & 77.1 & 75.5 & 75.6 & 75.6 & 75.7 & 75.6 & 75.6 \\
\hline $6^{\prime}$ & 62.0 & 60.2 & 60.2 & 60.3 & 60.4 & 60.5 & 60.6 \\
\hline 4'- $-\mathrm{OCH}_{3}$ & 60.9 & 59.6 & 59.7 & 59.7 & 59.7 & 59.6 & 59.7 \\
\hline
\end{tabular}

${ }^{a}$ In $\mathrm{CD}_{3} \mathrm{OD},{ }^{b}$ In DMSO- $d_{6}$

\section{DISCUSSION}

Metarhizosides A-G (1-7), seven new polysubstituted benzene glucosides featured a 4'-O-methyl- $\beta$-glucopyranose unit, were isolated from the EtOAc extracts of marine-derived fungus $M$. anisopliae. Their structures were elucidated by NMR spectroscopy and chemical method. Compounds $\mathbf{1}$ and 2 showed moderate anti-inflammatory effect on the inhibition of the production of NO.

\section{Open Access}

This article is licensed under a Creative Commons Attribution 4.0 International License https://creativecommons.org/licenses/by/4.0/), which permits use, sharing, adaptation, distribution and reproduction in any medium or format, as long as you give appropriate credit to the original author(s) and the source, provide a link to the Creative Commons licence, and indicate if changes were made. The images or other third party material in this article are included in the article's Creative Commons licence, unless indicated otherwise in a credit line to the material. If material is not included in the article's Creative Commons licence and your intended use is not permitted by statutory regulation or exceeds the permitted use, you will need to obtain permission directly from the copyright holder. To view a copy of this licence, visit http://creativecommons.org/licenses/by/4.0/.

\section{Conflict of Interest Statement}

The authors declare no competing financial interest.

\section{REFERENCES}

1 JinLL, QuanCS, Hou XY, etal.Potential pharmacological resources: natural bioactive compounds from marinederived fungi. Mar Drugs, 2016,14(4):76-100

2 Hong JH, Jang S, Heo YM, et al. Investigation of marine-derived fungal diversity and their exploitable biological activities. Mar Drugs, 2015,13(7):4137-4155

3 Zhu G, Kong F, Wang Y, et al. Cladodionen, a cytotoxic hybrid polyketide from the marine-derived Cladosporium sp. Oucmdz-1635. Mar Drugs, 2018,16 (2):71-78

4 Pye CR, Bertin MJ, Lokey RS, et al. Retrospective analysis of natural products provides insights for future discovery trends. Proc Natl Acad Sci U S A, 2017,114(22):5601-5606

5 Carroll AR, Copp BR, Davis RA, et al. Marine natural products. Nat Prod Rep, 2019,36(1):122-173

6 Blunt JW, Carroll AR, Copp BR, et al. Marine natural products. Nat Prod Rep, 2018,35(1):8-53

7 Blunt JW, Copp BR, Keyzers RA, et al. Marine natural products. Nat Prod Rep, 2017,34(3):235-294

8 Blunt JW, Copp BR, Keyzers RA, et al. Marine natural products. Nat Prod Rep, 2015,32(2):116-211

9 Rateb ME, Ebel R. Secondary metabolites of fungi from marine habitats. Nat Prod Rep, 2011,28(2):290-344

10 Saleem M, Ali MS, Hussain S, et al. Marine natural products of fungal origin. Nat Prod Rep, 2007,24(5):1142-1152

11 Blunt JW, Copp BR, Munro MHG, et al. Marine natural products. Nat Prod Rep, 2004,21(1):1-49

12 Jegorov A, Sedmera P, Matha V. Biosynthesis of destruxins. Phytochemistry, 1993,33(6):1403-1405

13 Chen HC, Yeh SF, Ong GT, et al. The novel desmethyldestruxin B2, from Metarrhizium anisopliae, that suppresses hepatitis B virus surface antigen production in human hepatoma cells. 1995,58(42):527531

14 Jegorov A, Sedmera P, Havlíček V, et al. Destruxin Ed1 a cyclopeptide from the fungus Metarrhizium anisopliae. Phytochemistry, 1998,49(6):1815-1817

15 Fujii Y, Tani H, Ichinoe M, et al. Zygosporin D and two new cytochalasins produced by the fungus Metarrhizium anisopliae. J Nat Prod, 2000,63(1):132-135

16 Vázquez MJ, Albarrán MI, Espada A, et al. A new destruxin as inhibitor of vacuolar-type H+-ATPase 
of Saccharomyces cerevisiae. Chem Biodivers, 2005,2(1):123-130

17 Azumi M, Ishidoh KI, Kinoshita H, et al. Aurovertins F-H from the entomopathogenic fungus Metarrhizium anisopliae. J Nat Prod, 2008,71(2):278-280

18 Wu X, Lin S, Zhu C, et al. Homo- and heptanor-sterols and tremulane sesquiterpenes from cultures of Phellinus igniarius. J Nat Prod, 2010,73(7):1294-1300

19 ChenXL,WuM,TiHH, etal. Threenew 3,6-dioxygenated diketopiperazines from the basidiomycete Lepista sordida. HeIv Chim Acta, 2011,94(8):1426-1430

20 He F, Sun YL, Liu KS, et al. Indole alkaloids from marine-derived fungus Aspergillus sydowii scsio 00305. J Antibiot, 2012,65(2):109-111

21 Zhang M, Wang WL, Fang YC, et al. Cytotoxic alkaloids and antibiotic nordammarane triterpenoids from the marine-derived fungus Aspergillus sydowi. J Nat Prod, 2008,71(6):985-989

22 Wang WJ, Xiao W, Liu JJ, et al. Two new terpenoids from Talaromyces purpurogenus. Mar Drugs, 2018,16(5):150-159

23 Wen HL, Liu XR, Zhang Q, et al. Three new indole diketopiperazine alkaloids from Aspergillus ochraceus. Chem Biodivers, 2018,15(4):e1700550-e1700558

24 Wang WJ, Gong JJ, Liu XR, et al. Cytochalasans produced by the coculture of Aspergillus flavipes and chaetomium globosum. J Nat Prod, 2018,81(7):15781587

25 Duus J, Gotfredsen CH, Bock K. Carbohydrate structural determination by NMR spectroscopy: Modern methods and limitations. Chem Rev, 2000,100(12):4589-4614

26 Isaka M, Haritakun R, Supothina S, et al. Nhydroxypyridone alkaloids, chromone derivatives, and tetrahydroxanthones from the scale-insect pathogenic fungus Orbiocrella sp. Bcc 33248. Tetrahedron, 2014, 70(48):9198-9203

27 Bunyapaiboonsri T, Yoiprommarat S, Khonsanit A, et al. Phenolic glycosides from the filamentous fungus Acremonium sp. Bcc 14080. J Nat Prod, 2008,71(5):891894

28 Smith F. The constitution of mesquite gum. Part III. The structure of the monomethyl glucuronic acid component. J Chem Soc, 1951:2646-2652

(Received Jan. 15, 2020; revised Mar. 16, 2020) 